FEDERAL RESERVE BANK OF SAN FRANCISCO

WORKING PAPER SERIES

\title{
Subprime Mortgage Delinquency Rates
}

\author{
Mark Doms \\ Federal Reserve Bank of San Francisco \\ Fred Furlong \\ Federal Reserve Bank of San Francisco \\ John Krainer \\ Federal Reserve Bank of San Francisco
}

November 2007

Working Paper 2007-33

http://www.frbsf.org/publications/economics/papers/2007/wp07-33bk.pdf

The views in this paper are solely the responsibility of the authors and should not be interpreted as reflecting the views of the Federal Reserve Bank of San Francisco or the Board of Governors of the Federal Reserve System. 


\title{
Subprime Mortgage Delinquency Rates
}

\author{
Mark Doms, Fred Furlong, and John Krainer* \\ Federal Reserve Bank of San Francisco \\ 101 Market Street \\ San Francisco, CA 94105
}

November 2007

\begin{abstract}
We evaluate the importance of three different channels for explaining the recent performance of subprime mortgages. First, the riskiness of the subprime borrowing pool may have increased. Second, pockets of regional economic weakness may have helped push a larger proportion of subprime borrowers into delinquency. Third, for a variety of reasons, the recent history of local house price appreciation and the degree of house price deceleration may have affected delinquency rates on subprime mortgages. While we find a role for all three candidate explanations, patterns in recent house price appreciation are far and away the best single predictor of delinquency levels and changes in delinquencies. Importantly, after controlling for the current level of house price appreciation, measures of house price deceleration remain significant predictors of changes in subprime delinquencies. The results point to a possible role for changes in house price expectations for explaining changes in delinquencies.
\end{abstract}

* The views presented are those of the authors and not necessarily those of the Federal Reserve System. The authors would like to thank Chris Foote, and participants at the 2007 Federal Reserve System Regional Conference, and Abigail Urtz and Annie Zhang for excellent research assistance. 


\section{Introduction}

Over the past decade, the subprime mortgage market has grown remarkably; by some estimates, subprime lending has grown from about 5 percent of all mortgage originations in 1994 to nearly 20 percent of all mortgage originations in $2005 .{ }^{1}$ During this same time period, the homeownership rate leaped by five percentage points, average house prices increased by more than a factor of two, and countless households liquefied home equity gains through cash-out refinancing.

However, recent increases in subprime mortgage delinquency rates (SMDR) have led to a reassessment of the social gains to the expansion of subprime lending and have prompted a search for the factors that contributed to this problem. Some speculation focuses on the relaxation of lending standards by mortgage issuers, such as the underwriting of loans with high loan-to-value ratios, high loan-to-income ratios, little or no documentation of income, and so on. This relaxation of lending standards would tend to increase the riskiness of the subprime borrower pool, and therefore it would not be altogether surprising for delinquencies to increase.

In addition to a riskier borrower pool, other factors may have contributed to the observed changes in SMDR. Those factors could include economic conditions. For instance, it would not be surprising to see an increase in the subprime delinquency rate in local economies where the unemployment rate increased.

In addition to local economic conditions and the riskiness of the borrower pool, relatively recent changes in house prices in the local market may also affect the SMDR and changes in the SMDR. For instance, distressed borrowers in strong housing markets

\footnotetext{
${ }^{1}$ See Gramlich (2004) and Avery and Canner (2006) and Avery, Brevoort, and Canner (2007) for estimates of the size of subprime or "high-priced" mortgage lending.
} 
have more alternatives to delinquency than do distressed borrowers in markets with flat of falling house prices. Those alternatives include selling the home and paying the loan off and possibly refinancing. Additionally, homeowners in strong housing markets have greater incentive to keep the mortgage current; if there is a potential capital gain on the house and if you default, you also risk giving up some or even all of that capital gain. House prices may also affect the observed SMDRs in other ways. For instance, when the pace of house price appreciation declines, some homeowners may lower their expectations about future house price appreciation, and hence may lower their demand for housing.

In this paper, we attempt to decipher the relative importance of these three stories - riskier borrower pool, changing economic conditions, and recent housing price behavior-on the recent behavior of the SMDRs by exploiting the rich regional variation in SMDRs and also in the changes in SMDRs. To preview the results, we find a role for all three candidate explanations. However, the recent behavior of house prices is the strongest correlate with the SMDRs and changes in the SMDRs. However, it is not merely low or negative house price appreciation that is correlated with the SMDR. In addition, changes in the rate of house price appreciation remain significant predictors of changes in subprime delinquencies. Thus, the results point to a possible role for changes in expectations for house price appreciation and, by extension, for housing demand, that is potentially not confined to the subprime household sector.

The paper is organized as follows. In section 2, we provide some background on the subprime market and present some stylized facts on the SMDRs. Section 3 explores 
the economic considerations that enter the mortgage delinquency/default decision. Section 4 presents the empirical results and Section 5 concludes.

\section{Subprime mortgage markets and SMDRs}

One hurdle facing researchers in the subprime market area is that there is no precise definition of "subprime." Generally speaking, "subprime" is a lender-given designation for the group of marginal borrowers that have some sort of credit impairment or lack of credit history. ${ }^{2}$ These credit impairments imply that subprime loans are riskier and higher-priced than loans to prime borrowers. The industry sometimes lumps subprime into the general class of nonprime borrowers, which also includes the so-called alt-A borrowers. Alt-A borrowers are thought to be better credit risks than subprime. Instead of a credit impairment associated with the borrower generally, alt-A loans are often thought to be non-prime because of some feature of the specific loan arrangement, such as low documentation, high loan-to-value, high payment-to-income, or some combination of these traits. Anecdotally, much of the recent innovation in mortgage contract design, such as the proliferation of interest-only loans and option-ARMs, has been to meet the growing housing demand of alt-A borrowers. ${ }^{3}$

Prior to 1980 , subprime lending was essentially curtailed by state usury laws that were particularly binding during the period of high nominal interest rates in the 1970s. Following banking deregulation, banks and other lenders were much less constrained in

\footnotetext{
${ }^{2}$ See Chomsisengphet and Pennington-Cross (2006) for a nice discussion of the development of subprime mortgage lending in the U.S.

${ }^{3}$ See Doms and Krainer (2007) for an analysis of recent trends in expenditures on housing by U.S. households.
} 
their ability to charge risk-based interest rates. Despite deregulation in the early 1980s, the subprime market did not bloom in earnest until the late 1990s. Why exactly the market developed so slowly has been a subject of research interest. ${ }^{4}$

Although "subprime" is not rigorously and consistently defined in the mortgage industry, one firm, First American LoanPerformance (FALP), has produced a number of statistics on regional SMDRs based on subprime mortgages in its database. The delinquency rate is defined as the percent of subprime loans that are delinquent 60 days or more. The data, which are from 2005 and 2006, contain observations on 309 metropolitan statistical areas (MSAs), and form the basis of our analysis. ${ }^{5}$ It is worth noting that the FALP data do not represent the entire universe of mortgages; also, estimates of delinquency rates on subprime mortgages vary among sources, reflecting differences in the definition of subprime and sample coverage. However, where possible, we have compared the FALP data to those from other sources and have found high correlations among them.

As shown in figure 1, the FALP data show considerable regional variation in the SMDRs in 2006 and 2005. In terms of the 2006 SMDRs, the median among the 309 MSAs was $12.2 \%$, with a range from about $3 \%$ to $25 \%$. MSAs near the Gulf Coast that were severely affected by Hurricane Katrina were among those with the highest SMDRs. Overall, however, the MSAs with the highest SMDRs tend to be located in the Midwest; of the 18 MSAs with the highest SMDRs in 2006, 14 were in Michigan or Ohio.

\footnotetext{
${ }^{4}$ Some of the recent papers on financial innovation and its consequences include Campbell and Hercowitz (2006), Doms and Krainer (2007), Dynan, Elmendorf, and Sichel (2006), and Girardi, Rosen, and Willen (2006).

${ }^{5}$ These data were collected from the online edition of the Wall Street Journal.
} 
In terms of changes in SMDRs, nearly all MSAs posted increases from 2005 to 2006. The median change was about 3 percentage points, and the largest increase was 11 percentage points. Of the 309 MSAs in the sample, only 25 had decreases in their SMDRs, with the sharpest declines among MSAs near the Gulf Coast. Of the 18 MSAs that posted the largest increases, 12 were in California and 3 were in Massachusetts. These MSAs typically had relatively low rates at the end of 2005.

\section{Determinants of subprime mortgage performance}

The decision to become delinquent on a mortgage depends on both the ability and the willingness of the borrower to repay the loan. Therefore, when examining regional variation in SMDRs, it is useful to examine the factors that would vary regionally that would affect both the ability to stay current and also the willingness to stay current on a mortgage.

In terms of the ability to stay current, there are two factors that we attempt to identify. The first is the riskiness of the borrower pool at the regional level, and the second is the set of the local economic conditions that might be expected to impact borrower income streams. In terms of the riskiness of the borrower pool, the expansion of subprime and the easing of credit constraints in general seem to have resulted in a large influx of borrowers who formerly received less or no credit at all (see Doms and Krainer (2007)). All else held constant, this type of development should lead to a higher SMDR. Our analysis seeks to exploit cross-sectional differences in observable risk measures to search for a relationship between risk and eventual delinquency. Why these 
regional differences emerge in the first place is beyond the scope of this current paper, but is addressed in other ongoing research.

Local economic conditions may affect subprime borrowers more than prime borrowers because subprime borrowers generally are thought to be more vulnerable to income or liquidity shocks that damage their ability to repay a loan. Therefore, local economies that have suffered adverse economic shocks would be expected to have greater SMDRs. In our analysis, we will look at MSA-level unemployment rates and employment growth rates as proxies for these local economic conditions.

Our approach to measuring the willingness to stay current on a mortgage is to examine changes in house prices. It is now standard to model the mortgage default decision as an option model. ${ }^{6}$ If the value of the house is less than the value of the mortgage, then the default option is "in the money" and the borrower is predicted to exercise that option. Under this paradigm, the most important variables to look at are changes in, and volatility of, house prices. Broadly speaking, changes in house prices should be negatively correlated with delinquency rates, as house price declines should eat into the borrower's equity cushion. It may not be necessary for house prices to decline outright in order for the default option to be in the money. Given the leverage that homeowners can deploy to finance their housing purchases, it is possible that house prices do increase, but by too little to cover the cost of the leverage. ${ }^{7}$ One way of attempting to measure cross-sectional differences in leverage employed in this paper is to look at differences in the ratio of mortgages that are not for owner-occupier purchase. That is, given the belief that there was substantial speculation in real estate markets over

\footnotetext{
${ }^{6}$ See Deng, Quigley, and Van Order (2000) for recent contributions and as well as a guide to a long literature on mortgages and options.

7 Another cost that homeowners have to consider is real estate closing costs.
} 
the past few years, we expect these speculators to show up in our mortgage data as nonowner-occupiers.

Another way to see how house price changes will figure into the default decision is to appeal directly to the theory of housing demand. Houses are, to some extent, factors of production in the local economy and their values should reflect economic conditions. House prices also embed expectations about future economic conditions and these expectations figure prominently in a household's housing demand. This is most clearly seen through the user cost of capital. A standard representation of the real after-tax user cost of capital is given by

$$
u_{t}=\left(i_{t}+n_{t}\right)(1-\operatorname{tax})+\delta_{t}-E_{t} \Delta P_{t+1}
$$

The user cost is increasing in the real mortgage rate (i), the property tax rate (n), and the depreciation rate on the housing asset $(\delta)$. The user cost is increasing in the marginal tax rate, tax. The user cost is decreasing in the expected real capital gain, as these gains accrue to household wealth. All other things held equal, increases (decreases) in expected appreciation, $E_{t} \Delta P_{t+1}$, reduce (increase) the user cost and raise (lower) demand. This in itself could change house prices and change the share of income devoted to housing.

Of all these terms in the user cost, the term most likely to vary over different markets is the expected house price appreciation rate. In this analysis we will use realized price appreciation to measure expected appreciation. This choice reflects, in part, the strong evidence of persistence in real estate prices so that current rates of price appreciation are fairly reliable predictors of future appreciation rates (see Case and Shiller (1989)). To look at changes in the user cost and changes in demand that may lead 
to changes in the delinquency rates, we will look at changes in the rate of price appreciation.

\section{Empirical models of SMDRs}

This section presents a series of simple models for the SMDRs observed in 2005, 2006, and the change from 2005 to 2006 . As in the discussion in the previous section, we decompose our independent variables into three sets; measures of the riskiness of the borrower pool, measures of local economic conditions, and measures of house prices.

\subsection{Borrower risk}

We derive several measures of the riskiness of the borrowers' pool, including the APR's on loans from the 2004 and 2005 Home Mortgage Disclosure Act (HMDA) data and the share of loans that are subprime. ${ }^{8}$ Since 2004, the HMDA data include the interest rate of a mortgage loan if that rate (i.e., the annual percentage rate) is three percentage points higher than the rate on a comparable Treasury. For each MSA, we compute the median of this rate. ${ }^{9}$

The second set of measures of the riskiness of the borrower pool attempt to measure the share of mortgages that are subprime. One method is to use the HMDA and compute, in each year, the share of first lien mortgages issued that year that have an APR of at least 3 percentage points above the comparable Treasury. We modify this concept

\footnotetext{
${ }^{8}$ We also used the 2005 Decennial Census to construct a number of demographic variables that may be related to the riskiness of the borrower's pool. Such variables included the fraction of households in the lower fifth of the income distribution, the age profile of the MSA, and others. Including these measures does not affect the results that follow.

${ }^{9}$ We examined the distribution of APRs in the HMDA data for each MSA and computed measures other than the median. In our empirical work we found no substantial differences between using the median and other measures.
} 
by examining the change in the share of mortgages issued that are subprime from 2004 to 2005 — a large increase would indicate that the market is dipping deeper into the reservoir of risky borrowers. ${ }^{10}$

Combining the HMDA measure on loan prices and the share of HMDA mortgages that are subprime, figure 2 shows the changes in median mortgage rates and the changes in the shares of mortgage originations that are subprime by MSA. The regression line confirms the basic message in the scatter plot that the APRs went up in markets where subprime activity increased.

In terms of level of delinquencies, the first several columns of table 1 (which has results for 2005) and table 2 (which has results for 2006) contain the results from regressions of delinquency rates on our proxies for the riskiness of the borrower pool. ${ }^{11}$ For the 2005 SMDRs, the results in column (3) show there is a strong relationship between the share of loans in 2004 that were subprime and the subprime delinquency rate witnessed in 2005. Also, the observed interest rates in 2004 and 2005 are positively correlated with SMDRs. Similar results are witnessed in the first three columns in table 2 for 2006. One additional observation is that while these risk factors are always statistically significant, they do not tend to explain much of the variation in delinquency rates; about 28 percent in 2005 and only 15 percent in 2006.

When using these risk measures it is important to be mindful of the fact that the distribution of risk across different markets is not exogenously given. This, of course,

\footnotetext{
${ }^{10}$ The HMDA data represent flows and do not capture the stock of mortgages that are subprime. The FALP did provide data on the stock of mortgages that are subprime according to their database, and we have that data for 2006. Although the HMDA and FALP data on subprime mortgages are different concepts and also differ by definitions of subprime, for our sample of MSAs, the correlation between the two series is .76

${ }^{11}$ We omitted New Orleans and Gulfport from the 2005 regressions on the grounds that these delinquency rates were heavily influenced from the fallout from Hurricane Katrina.
} 
can lead to econometric problems if our risk measures are correlated with the error term in the regressions in tables 1 and 2. To explore this more fully, we exploit data published by Countrywide Financial that provides some insight into the source of variation in mortgage rates across markets. The data are from Countrywide's rate sheets for nonprime first-lien adjustable-rate mortgages. ${ }^{12}$

We plot the data in figure 3. Evidently, this particular mortgage lender conditioned its rates on more than just borrower-specific covariates such as loan-to-value, FICO score, or recent delinquency history. At that time, Countrywide also considered regional factors as well. The figure (and table 3) confirms our intuition that quoted subprime mortgage rates are negatively related to recent house price appreciation. This, of course, makes sense, seeing as the probability of a loan being repaid should be related to general market conditions. Risky borrowers can be bailed out by strong house price appreciation; likewise, relatively safe borrowers may still default if the adverse shock to house prices is severe enough. This has implication for interpreting the results from our analysis since these same market conditions are likely to figure into the homeowner/borrower's decision making process. Thus, it becomes difficult to disentangle the precise channel through which house prices are affecting the SMDR. Is it through changes in household demand for housing, or through changes in lending standards that altered the risk pool, or both?

Another relationship that emerges from figure 3 and table 3 is that subprime mortgage rates are related to the legal rights of lenders seeking to foreclose on collateral in case of a default. The foreclosure regimes are taken from Pence (2006). These

\footnotetext{
12 The rates were for full doc 2/28 ARMs for mortgage applicants with a credit score of 700 . The were current as of May 21, 2007, accessed at https://www.cwbc.com/NonPrimeRateSheet.asp?PuF=1
} 
regimes vary by state. We focus on the question of whether state law requires a lender to pursue foreclosure through the court system. Pence demonstrated that borrower-friendly legal regimes are associated with smaller sized mortgage loans to households. Our results suggest that interest rates may be one channel through which mortgage credit is rationed in the presence of different foreclosure regimes.

Note that these state-specific subprime mortgage spreads are not trivial in magnitude. Undoubtedly, there are other factors besides house price appreciation and foreclosure regime that help to explain this distribution of mortgage rates. Nevertheless, the data indicate that borrowers of similar creditworthiness in a high price-appreciation lender-friendly state such as California faced mortgage rates that were 65 basis points lower than in a low price-appreciation borrower-friendly state such as Ohio.

\subsection{Economic conditions}

The second set of variables used in the delinquency regressions are measures of local economic conditions, namely the unemployment rate and the growth rate in employment. On average across MSAs, the unemployment rate did not rise, but actually fell by .4 percentage points between 2005 and 2006. In local markets where unemployment rates increased, the level of unemployment also tends to be high, which could have strained borrowers' ability to repay their mortgages or sell their houses.

We experimented with the timing of the employment growth and unemployment rate variables, and we report specifications that appear to be the most correlated with SMDRs. As seen in column (4) of tables 1 and 2, the current and lagged unemployment rates have significant positive coefficients, while the coefficients on the employment growth 
variables are strongly negative (the stronger employment growth, the lower the SMDR). For both 2005 and 2006, the economic variables account for about 30-40 percent of the variance, a much larger fraction than our risk proxies.

\subsection{House price dynamics}

The next sets of variables we examine are house prices. Before moving to the regression results, figures 4 and 5 show the scatter plots between log changes in house prices and SMDRs for 2005 and 2006. High appreciation MSAs like Las Vegas and Miami tend to have low SMDRs, at least for these two years. Also interesting is the presence of many California MSAs like Bakersfield, Fresno, and Riverside-San Bernardino in the southeast quadrant of figures 4 and 5. Recall that these MSAs also figured prominently as markets that experienced large increases in subprime lending volumes (figure 2).

As confirmed by the ensuing regression results, the strong relationships displayed in the figures are robust to the inclusion of many other variables. The results in tables 1 and 2 show the relationship between changes in house prices during the current and previous year (a 2-year window) and SMDRs. As with the other sets of variables in our models, we experimented with many different sets of timing. The results strongly point to including the current and previous year's appreciation rate. For the 2006 results, the coefficient on the change in house prices in 2006 is nearly identical to that for 2005; for the 2005 SMDR model, the change in house prices in 2005 is smaller in magnitude than the 2004 house price change coefficient at a 99 percent level. 
The last columns in tables 1 and 2 show the results with all of the risk, economic and house price variables. Of particular note is the fact that the coefficients on the house price variables do not change much when the economic and risk variables are also included. This result may not be that surprising given the strong relationship between house prices and SMDRs that was displayed in several of the earlier figures.

To better appreciate the effect that house price appreciation has had on delinquencies, it is useful to consider the case of Fresno, CA. Fresno experienced a surge in subprime lending between 2004 and 2005 when the high-priced share of total loans leaped from 9 percent to 33 percent of total first lien mortgages originated. In 2006 the subprime delinquency rate was about 8 percent-below the national average of 12 percent. But house price appreciation in Fresno between 2004 and 2006 was 31 percent, significantly above the national average of 18 percent over that time period. ${ }^{13}$ According to the specification in table 1 , this excess appreciation above the median held down the subprime delinquency rate in Fresno by about 3 percentage points.

To explore the relationship between house prices and SMDRs a bit further, table 4 presents several additional specifications for the SMDRs in 2005 and 2006. The first specification change that is presented in columns 1 and 5 includes the 2-year change in house prices and this term squared. F-tests indicate that the presence of the quadratic term significantly improves the fit of the model. To some extent, this nonlinearity must reflect the fact that the SMDR cannot fall below zero, and the 2-year house price appreciation in some the MSAs in our sample was exceptional indeed.

\footnotetext{
${ }^{13}$ This is the average appreciation rate of the MSAs in our sample. The OFHEO national house price index registered a 15 percent appreciation rate from 2004.Q4 to 2006.Q4.
} 
To put the quadratic term into perspective, figure 4 shows the fitted values of the relationship between changes in house prices and delinquencies for 2005 and 2006. For both years, the function is concave, showing noticeably large increases in predicted delinquencies when house prices are flat or gain only a handful of percentage points. The curve for 2006 is slightly more concave than the curve for 2005. An interesting research question we are pursuing is why delinquencies were so much higher in 2006 than 2005 even after controlling for the variables in our model.

What is perhaps the most surprising aspect of the results in figure 4 is that the subprime delinquency rate in 2006 remains high even in markets that have experienced rather high rates of house price appreciation. One theory that we explore is the deceleration in house prices boosted delinquencies, as deceleration in house prices may make housing a less attractive investment. We examined this issue in several ways. First, using the HMDA data, we compute the share of subprime mortgages that are nonowner occupied. We call this the "investment share". The logic behind this variable is that owners of non-owner occupied units may be more likely to become delinquent. We have this measure for 2004 and 2005 and we take the average of the two years (we examined each separately as well but there is little differences in the results that follow).

Another variable we construct is the average share of mortgages originations that are refinancings. The pace of refinancing was high during our sample, usually averaging slightly over 50 percent nationwide. The intuition behind using the refinancing share variable is that it may identify markets where households refinanced and extracted equity, and thus increased their leverage. If this were to occur, we would imagine that the default probability on those loans would rise, all else held constant. Another possibility, 
however, would be that regional differences in refinance rates reflect the regional differences in mortgage interest rates that are driven by past house price appreciation, as depicted in figure 3 .

Finally, we construct a house price deceleration variable as the difference in house price appreciation in the two years of the delinquency date. For instance, for the SMDR in 2005 , we compute the difference between the house price appreciation in 2005 and that of 2004 .

Generally, we find that those MSAs that possessed a greater investment share also had higher delinquency rates (see table 4). The estimated coefficients on the variable are statistically significant of the expected sign. The investment share variable is economically significant as well. The predicted SMDR increases by 2 percentage points if the investment share variable is moved from the $25^{\text {th }}$ to the $75^{\text {th }}$ percentile. Moving from the $10^{\text {th }}$ to the $90^{\text {th }}$ has an effect of 3.5 percentage points on the SMDR. Note that the refinancing share is insignificant in all the specifications in which it appears. The house price deceleration variable also fails to be statistically significant in the delinquency level regressions.

Before concluding the empirical analysis of the distribution of subprime delinquency rates, we note that virtually all of the facts we have established so far also apply to the distribution of prime-borrower delinquency rates. To see this, we use statelevel data provided by the Mortgage Bankers Association (MBA). ${ }^{14}$ Despite the superior

\footnotetext{
${ }^{14}$ There are some differences between the sources for the FALP and MBA delinquency data. The FALP data used here are extracted from the universe of mortgage-backed securities that are securitized by nonagency institutions (i.e., not securitized by Fannie Mae or Freddie Mac). Given the sample, the FALP delinquency rates are constructed from individual loans. By contrast, MBA assigns the prime-subprime distinction according to the lender. Thus, the delinquency rate reported by a predominantly subprime lender feeds into the calculation of the subprime delinquency rate only. Despite these differences, we have replicated the basic results in tables 1 and 2 at the state level using the MBA subprime data.
} 
credit quality of the prime borrowers, the correlation between the prime and subprime delinquency rates reported by the MBA is surprisingly high-.94 in 2006.

In table 6 we run the same basic regressions for prime delinquency rates as in table 2 for subprime. We have even greater problems identifying borrower risk measures for the prime regressions. However, in columns 1 and 2 we note that prime delinquency rates tend to be higher in states where subprime interest rates were higher, and where overall subprime lending activity was higher. We also see that economic conditions and recent changes in house prices explain a large part of the variation in prime delinquency rates, although the estimated coefficients on all of these variables are much smaller than was the case in the subprime regressions.

\subsection{Empirical models of changes in the SMDR}

We observe the same basic phenomena from the previous sections when we examine changes in the delinquency rate. Increases in risk tend to be followed by increases in the MSA-level subprime delinquency rate (see columns 1 and 2 of table 6).

Regarding changes in delinquency rates, despite the broader trend of declining unemployment rates at the MSA level, in some places unemployment did rise, and this rise was accompanied by changes in the SMDR over the same time period (column 3 of table 6).

As with the 2006 delinquency level regressions, changes in house price appreciation rates are strongly correlated with changes in SMDRs. This can be inferred from columns 4 and 5 of table 6 . MSAs that experienced a combination of strong house price appreciation between 2002 and 2004 and then relatively weak appreciation between 
2004 and 2006 tend to have increases in the SMDR. In column 6 of table 6 we include the change in one-year appreciation rates from 2005 to 2006, as well as a dummy variable taking the value of one if the level of the 2005-2006 appreciation rate is less than 5 percent. ${ }^{15}$ The estimated coefficient on the deceleration variable is negative and significant. But it is notable that the level effect in 2006 house price appreciation is still positive and significant. These results are consistent with the notion that slowing of house prices may have caught subprime borrowers off guard and contributed to rising delinquencies in those MSAs, and particularly so in markets where the most recent homebuyers would be unable to recoup their purchasing price net of transaction costs. Applying these results, we should expect higher delinquencies in MSAs where rapid price appreciation gives way to slower or negative appreciation.

House price deceleration is expected to have the biggest effect on the most vulnerable class of borrowers. However, a price deceleration should have an effect on less constrained prime borrowers as well. This is because house price appreciation rates are autocorrelated; households that observe lower-than-expected price appreciation are likely to revise downwards their expectations about future appreciation. This could translate into lower housing demand. To explore this possibility, we attempt to isolate the portion of house price appreciation that is not related to contemporaneous economic conditions. We adopt a two-stage approach. In the first stage we purge the most recent house price appreciation of contemporaneous changes in economic conditions. That is, we regress house price appreciation between 2004 and 2006 on the change in the

\footnotetext{
${ }^{15}$ The 5 percent cutoff is chosen to approximate the transaction cost of selling a house. The significance and the magnitude of the coefficient on the cutoff dummy variable in column 6 appear to be robust to changes in the cutoff.
} 
unemployment rate over that time period plus a contemporaneous and a lagged employment growth for the MSA. By construction, the residuals should be uncorrelated with the contemporaneous economic variables. In the second stage we regress the change in the subprime delinquency rate on the residuals from the first stage, lagged house price appreciation, the contemporaneous change in the unemployment rate, and the change in median interest rate on subprime loans between 2004 and 2005. When we regress changes in delinquencies back on economic conditions and the portion of house price appreciation that is uncorrelated with contemporaneous economic conditions, we see that all the estimated coefficients are strongly significant (see column 7 of table 6). Of particular interest is the coefficient on the generated regressor from the first stage. The relationship is negative; evidently, households in MSAs where recent house price appreciation has been lower than predicted by current economic conditions went delinquent at a greater rate than households where the slowing of prices is less pronounced.

One interpretation is that this "extra" slowdown in prices is correlated with expectations about future appreciation rates. This interpretation would be consistent with a relationship between changes in delinquencies and changes in demand for housing via a higher user cost. To the extent that this approach is able to identify changes in delinquency that are due to changes in expectations — an admittedly difficult task-this effect should not be contained solely in the subprime market, but should apply to all households that consume housing. 


\section{Conclusion}

The sharp rise in delinquency rates on subprime residential mortgages has raised concerns about credit underwriting practices and economic distress among borrowers, and has drawn the attention of policymakers at the Fed and elsewhere. No doubt, this is a complex issue, influenced by a number of different dynamics. Our analysis focuses on one of the potential dynamics, and we find that differences in the performance of subprime mortgages among MSAs may reflect in part the effects of house-price appreciation on the incentives and the opportunities of some mortgage borrowers to keep

loans current. Two of the potential channels through which house-price appreciation may affect the subprime delinquency rate that we suggest are the incentive to protect home equity associated with recent appreciation in house prices and the effect of changes in expectations about future house-price appreciation on the demand for housing. 


\section{References}

Avery, R., and Canner, G., 2006. "High Priced Mortgage Loans in 2005." Federal Reserve Bulletin.

Avery, R., Brevoort, K., and Canner, G., 2007. "The 2006 HMDA Data.” Forthcoming in the Federal Reserve Bulletin.

Campbell, J., and Hercowitz, Z., 2006. "The Macroeconomic Transitions to High Household Debt." Working paper.

Case, K., and Shiller, R., 1989. “The Efficiency of the Market for Single-Family Homes." American Economic Review.

Chomsisengphet, S., and Pennington-Cross, A., 2006. "The Evolution of the Subprime Mortgage Market." Federal Reserve Bank of St. Louis Review. January/February 31-56.

Deng, Y., Quigley, J., and Van Order, J., 2000. "Mortgage Terminations, Heterogeneity, and the Exercise of Mortgage Options." Econometrica, 68(2): 275-308.

Doms, M., and Krainer, J., 2007. "Mortgage Market Innovations and Increases in Household Spending." Federal Reserve Bank of San Francisco working paper.

Doms, M., Furlong, F., and Krainer, J., 2007. "House Prices and Subprime Mortgage Delinquencies." Federal Reserve Bank of San Francisco Economic Letter.

Dynan, K., Elmendorf, S., and Sichel, D., 2006. "Financial Innovation and the Great Moderation: What do the Household Data Say?" Federal Reserve Board of Governors working paper.

Girardi, J., Rosen, H., and Willen, P., 2006. "Do Households Benefit from Financial Deregulation and Innovation?" Working paper.

Gramlich, E., 2004. "Subprime Mortgage Lending: Benefits, Costs, and Challenges." Remarks made to the Financial Services Roundtable Annual Housing Policy Meeting, Chicago, Illinois, May 21, 2004.

Pence, K., 2006. "Foreclosing on Opportunity: State Laws and Mortgage Credit." Review of Economics and Statistics, vol. 88, pp. 177-182.

Poterba, J. 1984. "Tax Subsidies to Owner-Occupied Housing: An Asset Market Approach." Quarterly Journal of Economics (November) pp. 729-752. 


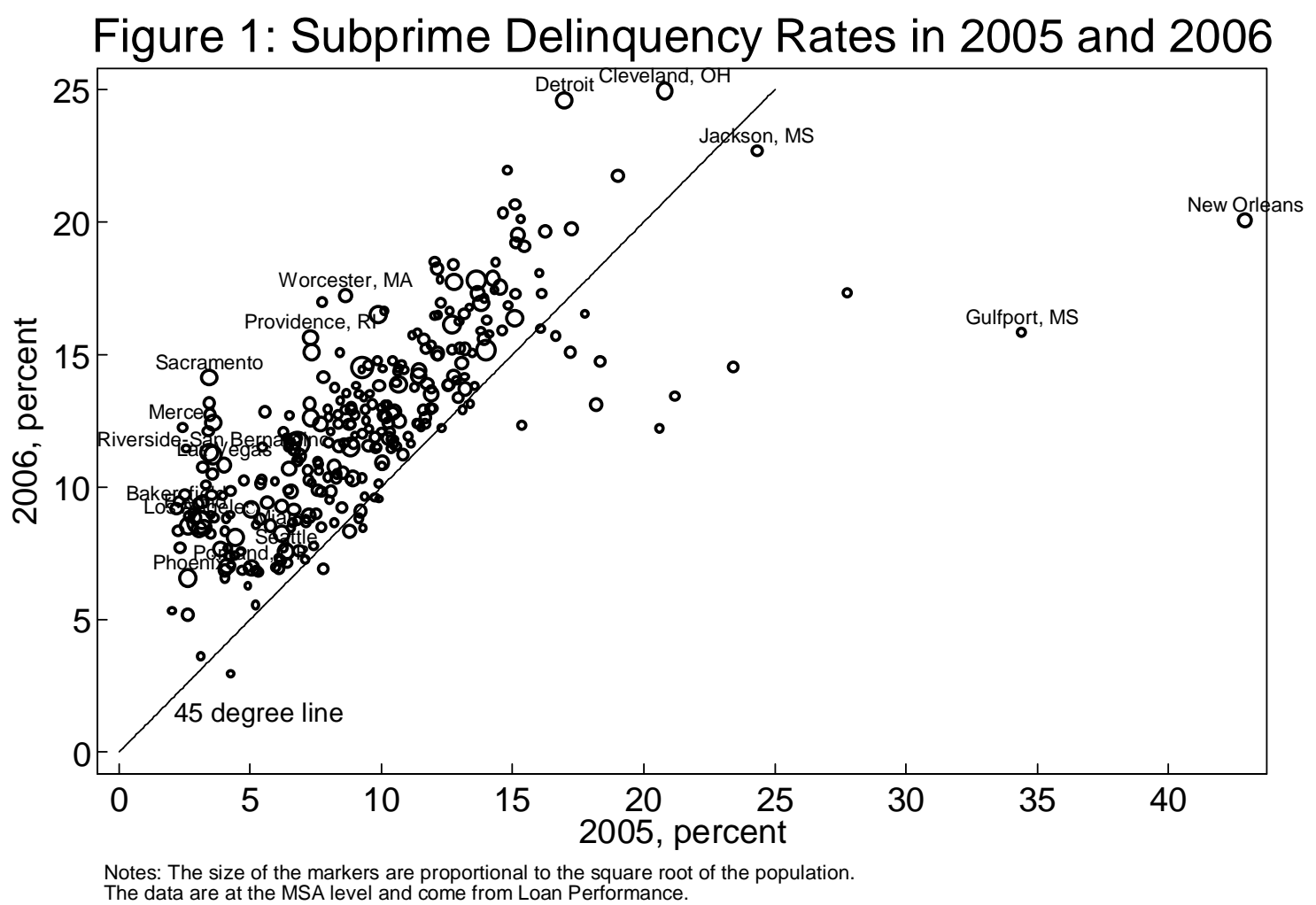

Figure 2: 2005-2004 Changes in Median Subprime Price

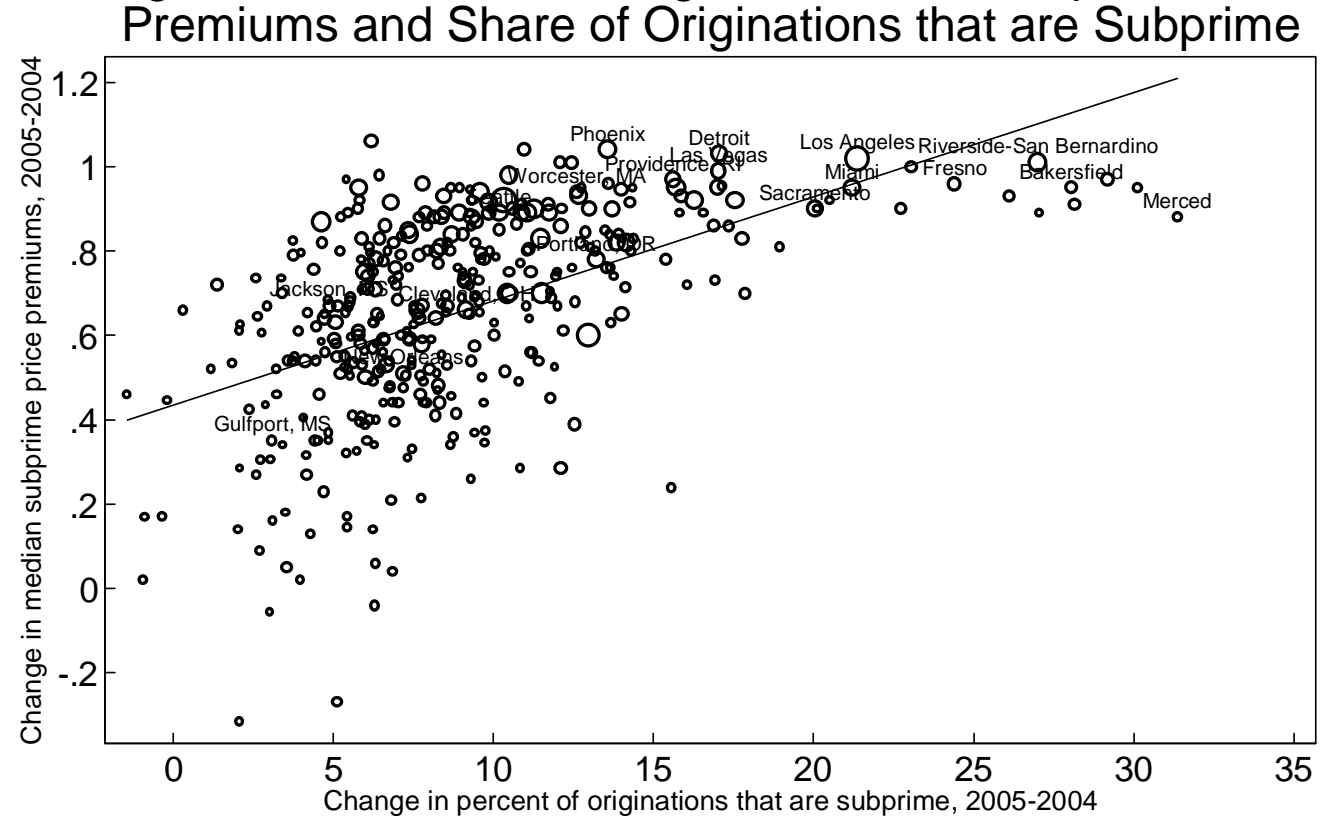

Notes: Subprime price premiums are provided in the HMDA data beginning in 2004. The size of the markers are proportional to the square root of the population. The data are at the MSA level and come from calcuations using the 2004 and 2005 HMDA data. 
Figure 3: Countrywide Wholesale Mortgage Interest Rates by State and Changes in House Prices, 2005Q1-2007Q1

700 credit score, full doc, 2/28, as of May 21, 2007

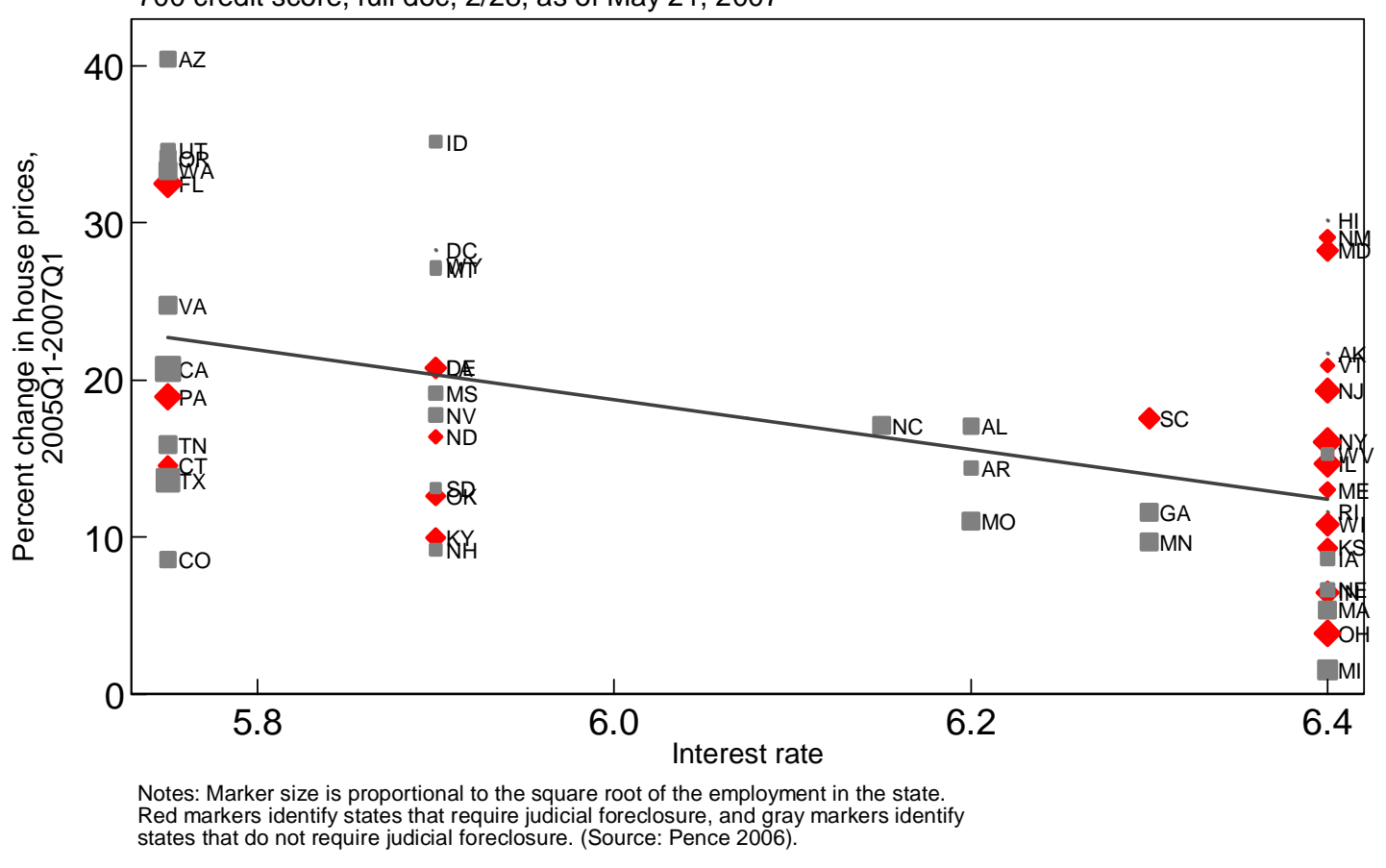


Figure 4: Changes in House Prices and SMDRs in 2005

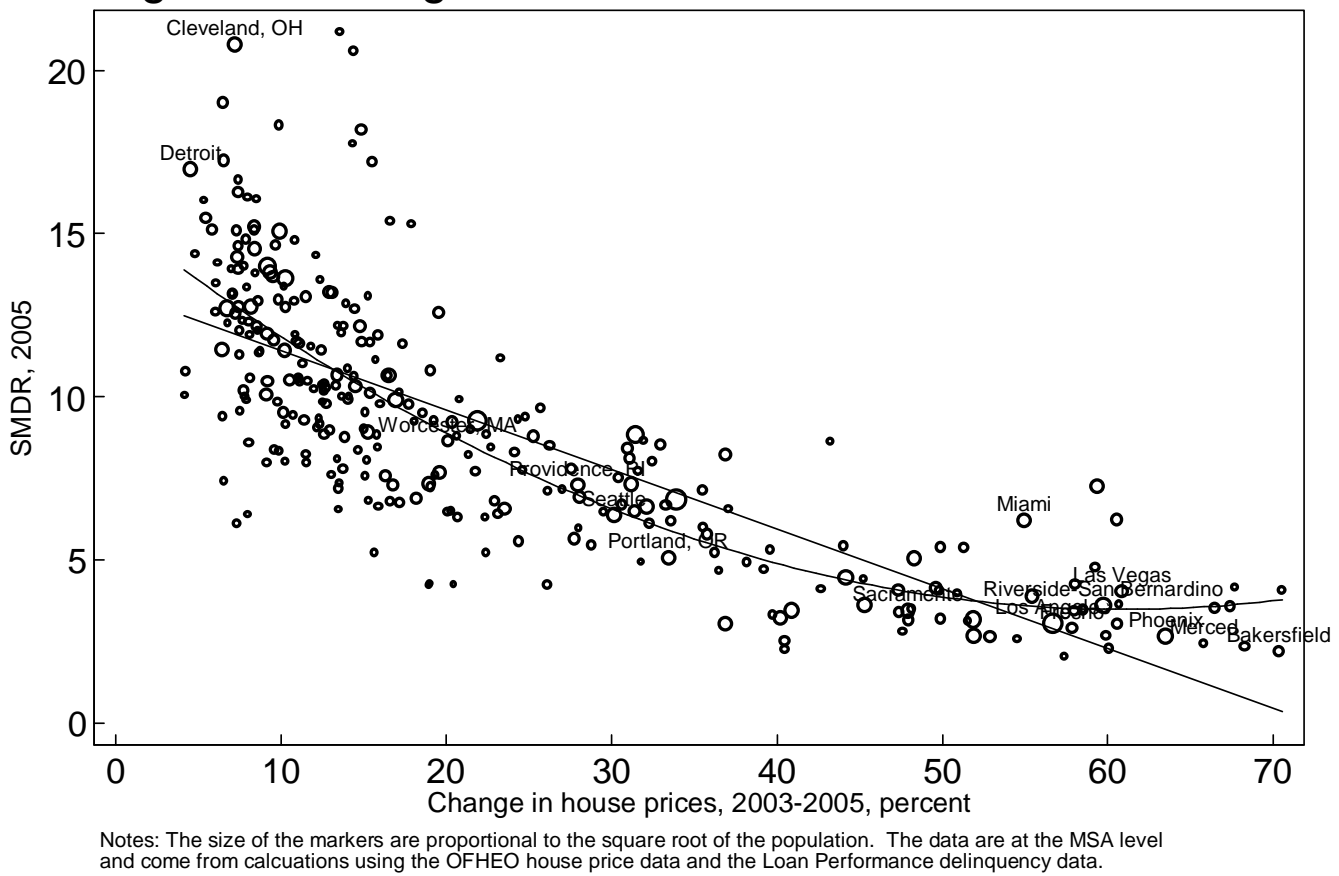

Figure 5: Changes in House Prices and SMDRs in 2006

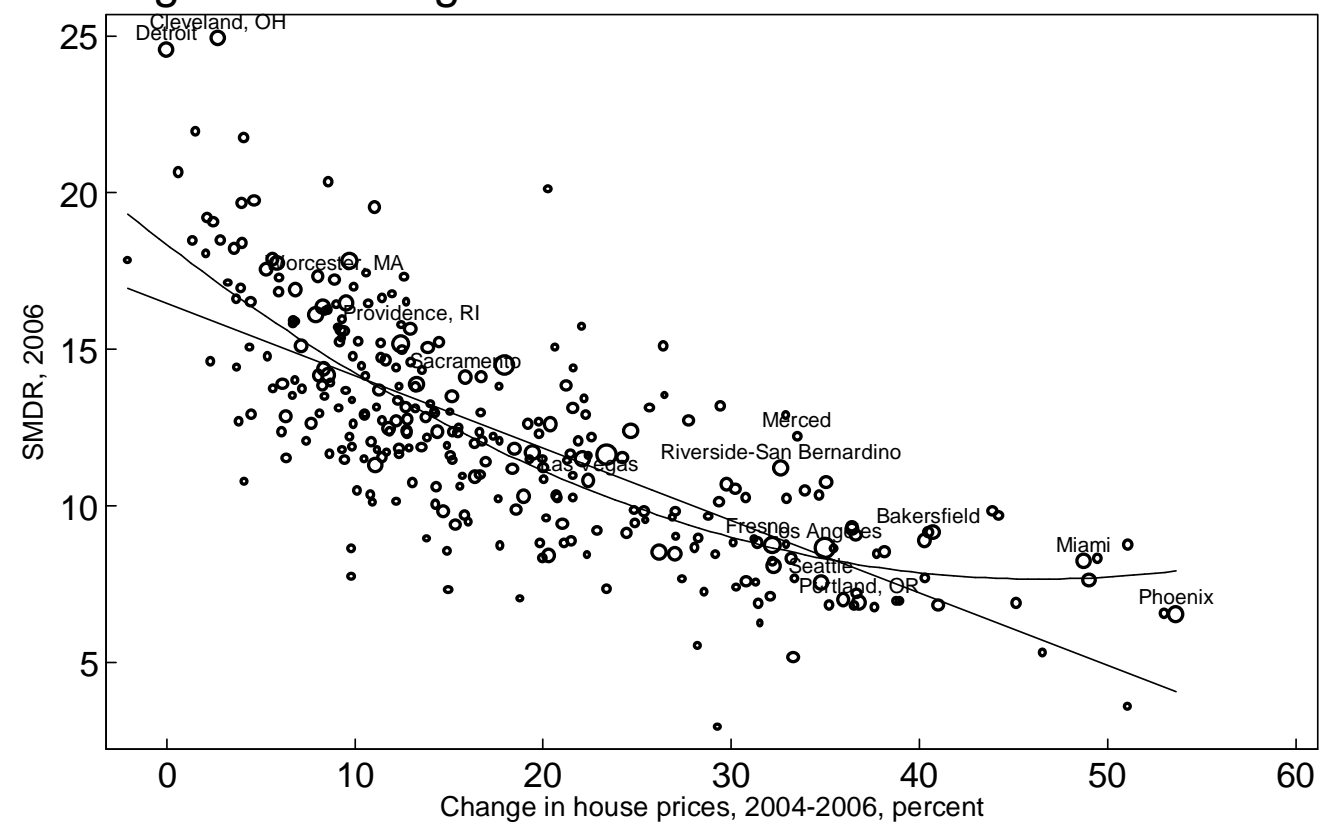

Notes: The size of the markers are proportional to the square root of the population. The data are at the MSA level and come from calcuations using the OFHEO house price data and the Loan Performance delinquency data. 
Figure 6: Predicted SMDRs and Changes in House Prices

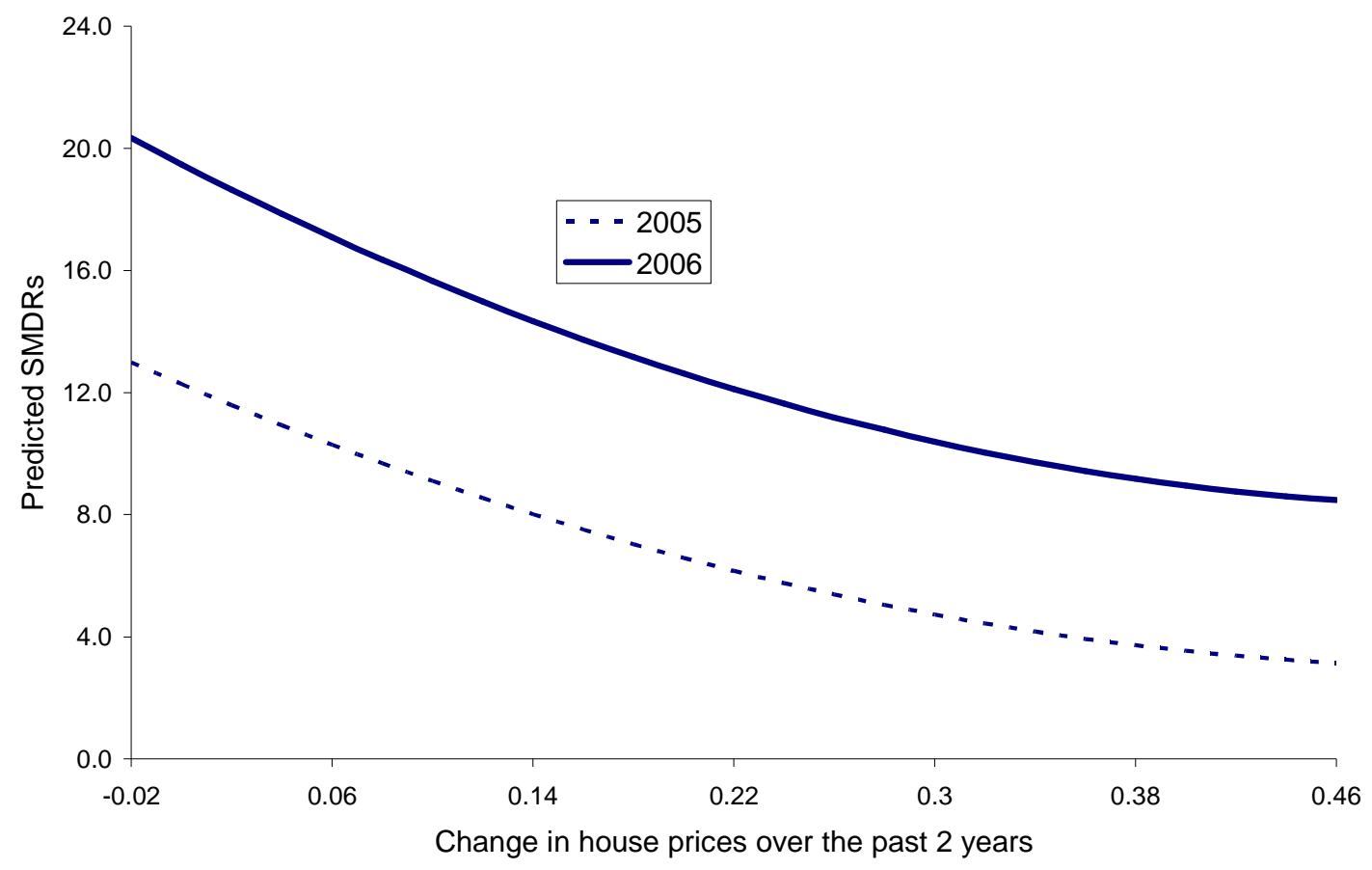


Table 1: Linear Models of Subprime Mortgage Delinquency Rates in 2005

Delinquency data are MSA-level from First American LoanPerformance

\begin{tabular}{|c|c|c|c|c|c|c|c|}
\hline \multicolumn{8}{|l|}{ Measures of risk } \\
\hline Median of HMDA APRs, 2004 & $\begin{array}{c}8.696 \\
(2.200)^{* *}\end{array}$ & & $\begin{array}{c}2.985 \\
(2.271)\end{array}$ & & & & $\begin{array}{c}-0.299 \\
(2.051)\end{array}$ \\
\hline Median of HMDA APRs, 2005 & 4.53 & & 5.25 & & & & 3.112 \\
\hline & (2.758) & & $(2.805)^{+}$ & & & & $(1.907)$ \\
\hline Share of originations that are subprime, 2004 & & $\begin{array}{c}0.746 \\
(0.125)^{\star *}\end{array}$ & $\begin{array}{c}0.478 \\
(0.130)^{\star *}\end{array}$ & & & & $\begin{array}{c}0.085 \\
(0.082)\end{array}$ \\
\hline Share of originations that are subprime, 2005 & & $\begin{array}{c}-0.359 \\
(0.044)^{\star *}\end{array}$ & $\begin{array}{c}-0.261 \\
(0.059)^{\star \star}\end{array}$ & & & & $\begin{array}{c}0.009 \\
(0.054)\end{array}$ \\
\hline \multicolumn{8}{|l|}{ Measures of economic conditions } \\
\hline Employment growth rate, 2003-2005 & & & & $\begin{array}{c}-0.341 \\
(0.111)^{\star *}\end{array}$ & & & $\begin{array}{c}0.019 \\
(0.056)\end{array}$ \\
\hline Unemployment rate, 2005 & & & & $\begin{array}{c}1.202 \\
(0.938)\end{array}$ & & & $\begin{array}{c}0.471 \\
(0.507)\end{array}$ \\
\hline Unemployment rate, 2004 & & & & $\begin{array}{c}2.542 \\
(0.663)^{\star *}\end{array}$ & & & $\begin{array}{c}1.198 \\
(0.614)^{+}\end{array}$ \\
\hline Unemployment rate, 2003 & & & & $\begin{array}{c}-3.169 \\
(0.776)^{* *}\end{array}$ & & & $\begin{array}{c}-1.363 \\
(0.434)^{* *}\end{array}$ \\
\hline \multicolumn{8}{|l|}{$\underline{\text { House prices }}$} \\
\hline Change in house prices, $2003-2004$ & & & & & & $\begin{array}{c}-0.276 \\
(0.040)^{\star *}\end{array}$ & $\begin{array}{c}-0.24 \\
(0.038)^{* *}\end{array}$ \\
\hline Change in house prices, $2004-2005$ & & & & & & $\begin{array}{c}-0.241 \\
(0.054)^{\star \star}\end{array}$ & $\begin{array}{c}-0.188 \\
(0.043)^{\star *}\end{array}$ \\
\hline Change in house prices, $2003-2005$ & & & & & $\begin{array}{c}-0.257 \\
(0.024)^{\star *}\end{array}$ & & \\
\hline Constant & $\begin{array}{c}-46.409 \\
(13.068)^{\star *}\end{array}$ & $\begin{array}{c}8.896 \\
(1.086)^{\star *}\end{array}$ & $\begin{array}{c}-26.719 \\
(11.633)^{*}\end{array}$ & $\begin{array}{c}8.776 \\
(1.780)^{\star \star}\end{array}$ & $\begin{array}{c}14.413 \\
(0.616)^{\star \star}\end{array}$ & $\begin{array}{c}14.411 \\
(0.616)^{\star \star}\end{array}$ & $\begin{array}{c}-1.702 \\
(4.858)\end{array}$ \\
\hline Observations & 307 & 307 & 307 & 296 & 307 & 307 & 296 \\
\hline R-squared & 0.34 & 0.34 & 0.39 & 0.37 & 0.65 & 0.65 & 0.73 \\
\hline
\end{tabular}

Robust standard errors in parentheses, weighted regressions using the square root of MSA population + significant at $10 \%$; ${ }^{*}$ significant at $5 \%$; ${ }^{*}$ significant at $1 \%$ 
Table 2: Linear Models of Subprime Mortgage Delinquency Rates in 2006

Delinquency data are MSA-level from First American LoanPerformance

\begin{tabular}{|c|c|c|c|c|c|c|c|}
\hline & (1) & (2) & (3) & (4) & (5) & (6) & (7) \\
\hline \multicolumn{8}{|l|}{ Measures of risk } \\
\hline \multirow[t]{2}{*}{ Median of HMDA APRs, 2004} & 1.81 & & -1.434 & & & & -2.097 \\
\hline & $(1.576)$ & & $(2.208)$ & & & & $(1.138)^{+}$ \\
\hline \multirow[t]{2}{*}{ Median of HMDA APRs, 2005} & 6.549 & & 6.603 & & & & 4.062 \\
\hline & $(3.366)^{+}$ & & $(3.221)^{*}$ & & & & $(1.469)^{* *}$ \\
\hline \multirow{2}{*}{ Share of originations that are subprime, 2004} & & 0.314 & 0.285 & & & & 0.07 \\
\hline & & $(0.108)^{* *}$ & $(0.119)^{*}$ & & & & $(0.082)$ \\
\hline \multirow[t]{2}{*}{ Share of originations that are subprime, 2005} & & -0.101 & -0.117 & & & & 0.063 \\
\hline & & $(0.043)^{*}$ & $(0.066)^{+}$ & & & & $(0.037)+$ \\
\hline \multicolumn{8}{|l|}{ Measures of economic conditions } \\
\hline Employment growth rate, 2004-2006 & & & & $\begin{array}{c}-0.439 \\
(0.134)^{\star *}\end{array}$ & & & $\begin{array}{l}-0.04 \\
(0.05)\end{array}$ \\
\hline Unemployment rate, 2006 & & & & $\begin{array}{c}0.654 \\
(0.679)\end{array}$ & & & $\begin{array}{c}0.103 \\
(0.393)\end{array}$ \\
\hline Unemployment rate, 2005 & & & & $\begin{array}{c}0.27 \\
(0.505)\end{array}$ & & & $\begin{array}{c}0.521 \\
(0.181)^{* *}\end{array}$ \\
\hline Unemployment rate, 2004 & & & & $\begin{array}{c}-0.29 \\
(0.545)\end{array}$ & & & $\begin{array}{l}-0.472 \\
(0.29)\end{array}$ \\
\hline \multicolumn{8}{|l|}{ House prices } \\
\hline Change in house prices, 2004-2005 & & & & & & $\begin{array}{c}-0.289 \\
(0.037)^{\star *}\end{array}$ & $\begin{array}{c}-0.282 \\
(0.047)^{* *}\end{array}$ \\
\hline Change in house prices, $2005-2006$ & & & & & & $\begin{array}{c}-0.31 \\
(0.069)^{* *}\end{array}$ & $\begin{array}{c}-0.302 \\
(0.041)^{\star *}\end{array}$ \\
\hline Change in house prices, $2004-2006$ & & & & & $\begin{array}{c}-0.295 \\
(0.035)^{\star *}\end{array}$ & & \\
\hline Constant & $\begin{array}{c}-25.227 \\
(14.137)+\end{array}$ & $\begin{array}{c}11.388 \\
(1.100)^{\star *}\end{array}$ & $\begin{array}{c}-13.106 \\
(14.587)\end{array}$ & $\begin{array}{c}11.396 \\
(1.674)^{* *}\end{array}$ & $\begin{array}{c}17.475 \\
(0.729)^{* *}\end{array}$ & $\begin{array}{c}17.489 \\
(0.738)^{* *}\end{array}$ & $\begin{array}{c}4.513 \\
(8.106)\end{array}$ \\
\hline Observations & 309 & 307 & 309 & 297 & 309 & 309 & 297 \\
\hline R-squared & 0.12 & 0.08 & 0.14 & 0.28 & 0.59 & 0.59 & 0.72 \\
\hline
\end{tabular}




\title{
Table 3: Countrywide Wholesale Mortgage Interest Rates by State and Changes in House Prices
}

\author{
Interest rates for 700 credit score, full doc, 2/28, as of May 21, 2007 \\ (2) \\ 0.174 \\ $(0.083)^{\star}$ \\ 0.156 \\ (3) \\ (4) \\ 0.164 \\ (5) \\ Require judicial foreclosure \\ $-0.018$ \\ $2006 q 3$ to $2007 q 1$ \\ (0.029) \\ $2006 q 1$ to $2007 q 1$

$\begin{array}{cc}-0.028 & -0.018 \\ (0.012)^{*} & (0.011) \\ & -0.018\end{array}$ \\ $2005 q 1$ to $2006 q 1$ \\ $(0.005)^{\star *}$ \\ $2005 q 1$ to $2007 q 1$ \\ $2004 q 1$ to $2005 q 1$ \\ Constant

$\begin{array}{cc}6.037 & 6.150 \\ 0.079)^{\star *} & (0.080)^{\star \star} \\ 47 & 47 \\ 0.10 & 0.20\end{array}$ \\ Observations \\ R-squared \\ 0.10 \\ 0.20 \\ $(0.071)^{*}$ \\ $(0.070)^{\star}$ \\ $(0.071)^{*}$ \\ test: dhpi0506=dhp0607 \\ Standard errors in parentheses \\ + significant at $10 \% ;{ }^{*}$ significant at $5 \% ;{ }^{* *}$ significant at $1 \%$ \\ Judicial foreclosure variable $=1$ for states requiring judicial foreclosure and $=0$ for states with no judicial \\ foreclosure requirement (Source: Pence 2006). \\ Regressions weighted by the square root of employment in the state.
}

Table 4: Further Results on SMDRs and House Prices, 2005 \& 2006

Delinquency data are MSA-level from First American LoanPerformance

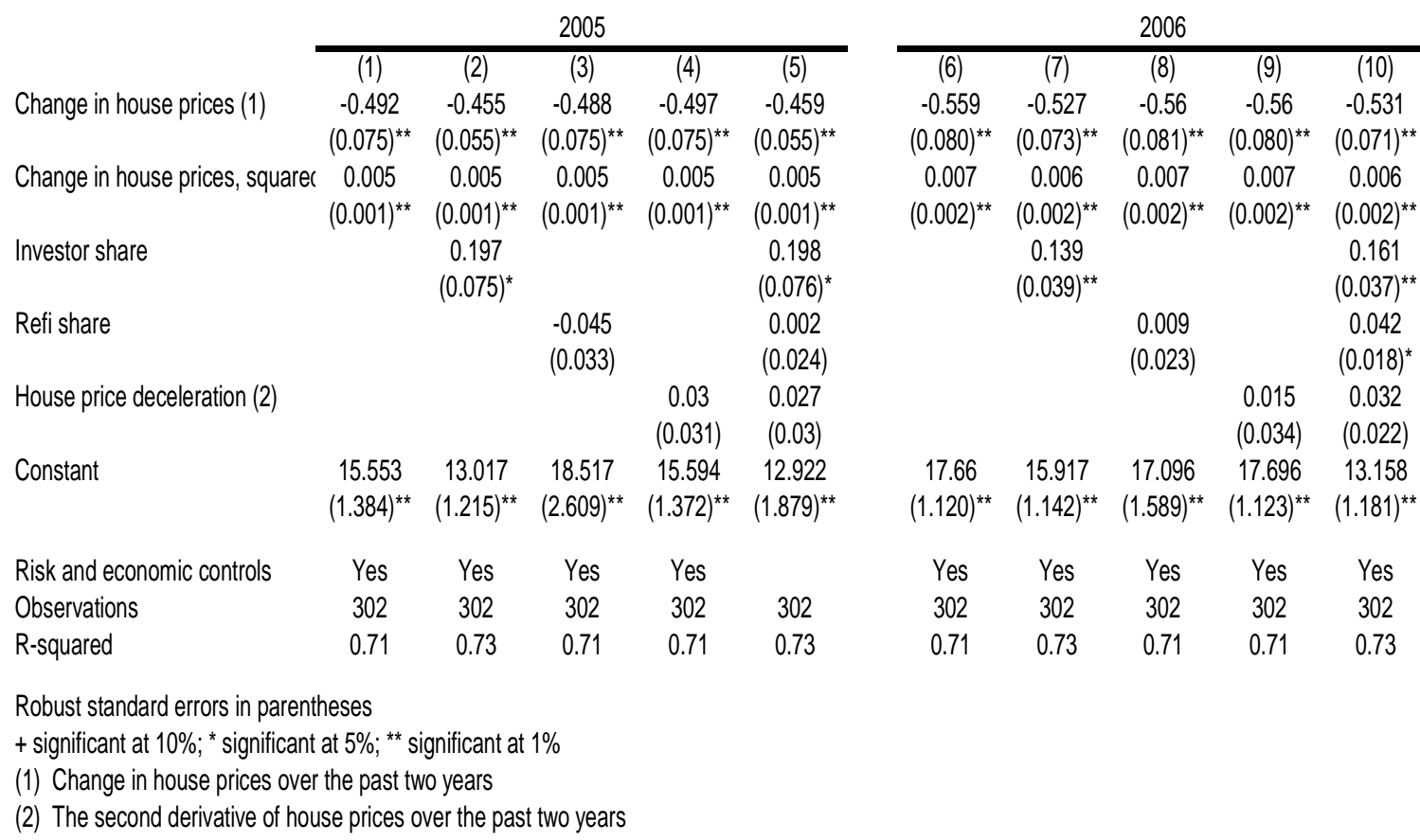




\section{Table 5: Linear Models of Prime Mortgage Delinquency Rates in 2006}

Delinquency data are state-level from Mortgage Bankers Association

\begin{tabular}{lccc} 
Measures of risk & $(1)$ & $(2)$ & $(3)$ \\
\hline Median of HMDA APRs, 2005 & -0.176 & & 0.490 \\
Median of HMDA APRs, 2006 & $(0.704)$ & $(.563)$ \\
& -1.093 & -1.799 \\
Share of originations that are subprime, 2005 & $(.594)^{+}$ & $(.548)^{\star *}$ \\
& & 0.046 & 0.057 \\
Share of originations that are subprime, 2006 & & $(.018)^{\star *}$ & $(.017)^{\star *}$ \\
& & 0.0257 & 0.04598 \\
& & $(.036)$ & $(.035)$
\end{tabular}

Measures of economic conditions

Employment growth rate, 2003-2005

Unemployment rate, 2004

$-0.072 \quad 0.002$

$(.025)^{\star *} \quad(.021)$

$-0.160 \quad-0.087$

(1.311) (.101)

Unemployment rate, 2005

0.323

$(.08)^{\star *}$

0.368

0.0434

$(.066)^{* *}$

Unemployment rate, 2006

(.091)

$-0.08$

(.097)

House prices

Change in house prices, 2004-2005

Change in house prices, 2005-2006

Change in house prices, 2004-2006

Constant

$\begin{array}{lllllll}8.431 & 0.511 & 7.924 & 0.649 & 2.126 & 2.131 & 1.058\end{array}$

$(3.021)^{\star *}(.379)(2.704)^{\star *}(.433)(.072)^{* *}(.157)^{\star *}(.341)^{\star *}$

obs

R-squared

$\begin{array}{ccccccc}51 & 51 & 51 & 51 & 51 & 51 & 51 \\ 0.13 & 0.09 & 0.29 & 0.48 & 0.36 & 0.47 & 0.68\end{array}$




\section{Table 6: Linear models of the change in SMDR, 2005-2006}

The dependent variable is the change in delinquency rates 2005-2006

Changes less than $-10 \%$ were omitted from the regressions

Delinquency data are MSA-level from First American LoanPerformance

House price change

2004-2006

Orthogonalized house

price changes 2004-

$2006^{\mathrm{a}}$

House price change

2002-2004

(1)

(2)

(3)

(4)

$-0.11^{\star *}$

(.012)

$0.17^{\star *}$

(6)

(7)

$.083^{\star *}$

(.011)

Change in

appreciation rates ${ }^{b}$

$-.093^{\star *}$

(.012)

$=1$ if $2005-2006$

appreciation $<5 \%$

$.704^{\star *}$

(.299)

Change in

unemployment rate 05 .

06

$2.58^{* *}$

$0.12^{* *}$

(.011)

(.011)

(0.012)

$.107^{\star \star}$

(.011)

(0.29)

$1.65^{\star *}$

$1.57^{\star *}$

$2.01^{\text {** }}$

(0.24)

(.24)

(.24)

Change in median

interest rate in MSA

$5.52^{\star *}$

$2.27^{\text {** }} \quad 2.83^{\text {** }} \quad 2.79^{\text {** }}$

(0.57)

(0.52)

(.502)

(.53)

Change in subprime share of total lending in MSA

$0.23^{\text {** }}$

(.026)

$\mathrm{R}^{2}$ adjusted

0.23

306
0.21

295
0.42

306
0.53

295

.51

295
0.52

295

${ }^{a}$ Orthogonalized from a regression of house price changes 2004 - 2006 on the change in unemployment 2005 - 2006, and employment growth in 2005 and 2006/

${ }^{\mathrm{b}}$ Calculated as 2005-2006 appreciation minus 2004-2005 appreciation. 